\title{
Stand Up Comedy: Language Play and Its Functions (Systemic Functional Linguistic Approach)
}

\author{
I Dewa Putu Wijana \\ idp_wijana@yahoo.com \\ Faculty of Cultural Sciences, Gadjah Mada University
}

\begin{abstract}
It is obviously misleading to regard that play-on-word activities are unimportant or trivial in human life. In many diverse societies, punning activities have very central roles in rituals as well as in cultural transformation processes. The importance of role played by punning activities attracts me to discuss the functions of language found in Stand Up Comedy, the most recent and popular comedy show broadcasted by Metro TV Station. This television program shows the skillfulness of comedians in telling jokes in front of its audience who are mostly teenagers or adolescents.

Joking activities play central roles in human life because of their various functions, especially to criticize various social conditions that happen in the speakers' community. However, to create unaggressive and constructive criticisms, the comedians build an intimate relation with their audience to create an effective deliverance. Consequently, they use certain moods of interaction using informal language styles which are full of ambiguities that can easily confuse audience's perceptions about many things. This is, of course, for the sake of eliciting audience's smiles and laughter.
\end{abstract}

Keywords: stand-up comedy, language play, contextual framing

\section{Introduction}

Halliday (1970) differentiates the social function of a language into two categories, namely ideational function and interpersonal function. This classification is similar to Brown and Yule's concept of transactional and interactional function (Brown \& Yule, 1983, 1-2). Ideational function concerns with the function to express ideas or thoughts. Meanwhile, interactional function is related to its function to create and maintain social interactions between the speakers.

The global era, which focuses on scientific and technological development, ideational or transactional function seems to get more attention, while the interpersonal or interactional is neglected. Therefore, interactive discourses, such as riddles and other types of language plays get the impact. The declination of researches' attention toward several types of interactional discourse, especially ones that contain language plays and the same kind, is mainly caused by the existence of negative opinions which consider that language plays are childish and inappropriate to use for discussing serious matters (Cook, 2000, 81).

Rejections against everything associated with language plays have occurred for along time. For example, Aristotle regards language plays can threat philosophy (Ulmer, 1988). Johnson views that language plays as "the fatal Cleopatra" which destruct Shakespeare plays (Redfern, 1984). Even more extremely, a literary critic describes language plays as a low quality activity. All these opinions are certainly illogical and often not objective, also inconsistent. They are totally not aware that rhyming concepts, such as alliteration, metaphor, and ironyseriously discussed in 
literary analyses areactually a representation of language plays (Cook, 2000, 81).

Oracles, implicit advices are essentially language plays. Shakespeare, a famous English literary writer often exploits language plays in his comedy or tragedy literary works. For example, When Hamlet's Mother got drunk because of the wine that has been filled in a poisonous pearl by a man whom she was in the party with. He shouted"Is this union here". Union is another word for referring to 'pearl' in the Elisabethan English besides the meaning of 'wedding party' that will bring his mother to her death. For his skill in playing on words, Shakespeare was even called "a dedicated punster"

In a very impressive Javanese traditional play performed by a famous group from Tulungagung once I watched in local television program, the fail of Arya Penangsang in defeating his long standing enemy Sultan Agung who is also popularly called Jaka Tingkir is caused by his incapability in interpreting the oracle (Sanepa) expressed by his adviser when his enemy was already face to face with him. The oracle is an implicit command: Rangkakna! The meaning intended by his adviser to him is 'Tusukkan/tikamkan kerismu' (Stabb your kris!). However, what he comprehended was 'sarungkan kerismu' (sheathe your kris!) because this word is accidently ambiguous (taksa). Because of his misinterpretation, Sultan Agung liberated from the tragedy, and at the end of the story, Arya Penangsang was killed by Suta Wijaya, Sultan Agung's son.

These facts clearly show that it is obviously misleading to regard that play on word activities are unimportant or trivial in human life. In many diverse societies, punning activities have very central role in rituals as well as in cultural transformation processes. For examples, in Gonds community (middle of India), men gather in the side of village when one of their member is passed away. They are riddling accompanied by drum beats (Cook, 2000, 79). Handleman $(1996,49)$ notes that African, Caribbean, and south East Asian societies, use riddles in various ritual ceremonies, such as marriages, funerals, wakes, religious worships, and the choice of a king. In East Toraja, riddles are played when they wake watching the dead before funeral. Meanwhile in West Toraja, the riddle reciting is done during the coming out of rice grains (Stokhof, 1980, 56; Wijana, 2014, 8). Riddle is one of discourse genres that is full of puns.

The other evident that proves the centrality of punnings in human life is the never ending comedy programs shown in visual mess media. The cease of one program is quickly replaced by the other. The fade of Srimulat popularity and its actors Timbul, Basuki, Eko, Topan, Lesus, etc. was succeeded by the emergence of Opera van Java that popularizes Parto, Sule, Aziz, etc. Afterwards we saw ILC (Indonesia Lawak Club) with Cak Lontong as its central joker. ILC might get its name from playing on ILC (Indonesia Lawyer Club). Probably it is just only the common people who know which one is funnier. Shop names often exploit play on words. In Yogyakarta there is a shop named Isakuiki (isaku iki 'Just this I can do'), reflex massages Kakiku (kakiku 'my foot'), restaurant Takashimura (Tak kasih murah 'I give you a cheap price), beauty salon La Risa (lariso 'hopefully sell well'), fried chicken small restaurant Kentucku Fried Chiken ( ken tuku fried chicken is asked to by fried chiken'). T Shirt business are also pond of puns in popularizing its designs. After Dagadu, Joger in Bali does the same thing. These kinds of activities are also found in Bandung and other cities as well.

The importance of role played by punning activities attracts me to discuss the functions of language found in Stand Up Comedy, the most recent and popular comedy show broadcasted by Metro TV Station. This television program shows the skillfulness of a comedian (comic according this program) in telling jokes in front of its audience who are mostly teenagers or adolescents. In every show, there are at least three comedians performing his/her joking skill about their experiences and showing their high capability in playing linguistic elements of various hierarchical levels. 


\section{Theoretical Frame Work}

Language variations used by the speakers in sociolinguistic perspectives are strongly influenced by extra linguistic factors that are varied but essentially the same between one theory and the others. In Systemic Functional Linguistics (SFL) theory used as an approach in this brief paper, the situational contexts are field, tenor, and mood (Halliday, 1978, 33; ). Field refers to what is happening, what speakers and hearers are doing, and the characteristics of the social actions being done by the interlocutors. Tenor refers to people involved in the verbal interactions which include their personal relationship (degree of intimacy), the role they play in that particular situation, etc. Mood refers to parts played by the language, all effects expected to gain by the interlocutors by using certain type of text including its symbolic organization, role, function, channel, and rhetorical mode as well. By this theoretical frame work, it can be hypothesized that the language variation used by the comedian or jokester in Stand Up Comedy Show to amuse the audience has various symbolic functions for gaining certain effects to the direct audiences who present in the TV studio, and the indirect audiences, all people outside the studio who watch the Stand UP Comedy program. It is certainly out of my capacity to able to discuss all Stand Up comedian discourses in this paper. Therefore, I will focus my attention to comical discourse episode delivered by a woman comedian named Wati Salsabila.

\section{Contextual Framing of Stand Up Comedy}

This section is intended to put the Stand Up Comedy discourse in the frame of three contextual aspects of systemic functional linguistics have been outlined above. The framing yields the following result:

Field: A comedian wants to tell his/her imaginative experiences to the audiences in order to amuse them.

Tenor: A comedian and audience who relatively have the same status, interact directly or indirectly in informal situation and intimate personal relationship.
Mood: The discourse delivered by the comedian should effectively amuse the audience, indicated by laugh and smile expressed or shown every time the jokester throw the jokes.

This contextual framing lead us to understand the language variation exploited in Stand Up Comedy discourse and its functions in the whole process of verbal interactions.

\section{Language Play in Stand Up Comedy}

Even though the discourse is delivered in humorous mood of interaction, this does not mean that the thematic structures the comedian want to convey are unserious matters. In many cases, the social problems implicitly criticized by the comedian are important issues being faced by the community for gaining quick response and improvements. In Wati Salsabila's discourse we can notice critics against various social issues, such as the attitude of some people to value more highly everything that come from outside than one they have already had passed down by their ancestors, as shown by the children naming. The ability of Indonesian medical doctors or might also be its other scientists is considered so low that they cannot make precise predictions of many things, such as the wrong prediction of birth. Many Indonesians are wasteful and consumptive. They can spend ten million rupiahs for shopping per day, and own 10 mobile phones, more than they really need. Many electronic cinemas have low quality because they are not seriously made, and more strikingly, most of them do not reflect the real social conditions. All of these can clearly be seen from various aspects, such as casting, unnatural dialogs, directing, story quality, etc. Social health and social welfare are also used to be the critic materials of Wati Salsabila's jocular discourse, such as the large numbers of mosquito and big families with bad economic condition.

To achieve effective deliverance, these thematic issues must be wrapped by the use of appropriate language style. The language style which is commonly used for delivering jocular texts and the sorts is informal style. 
Standard languages tightly bound by complicated grammatical rules are not suitable to use in joke telling activities (Apte, 1985, 190-191; Wijana, 1995, 141). Humorous text which is full of ambiguities can only develop in nonstandard varieties. Ambiguities, the most significant characteristics of humorous text, which can be created by various linguistic violations are difficult to appear in well-formed utterances that usually express accurate meanings. Ambiguities in humorous discourse constitute an effective tool to transfer two totally opposing perceptions, such as good and bad, honest and dishonest, important and trivial, etc. For all of these matters, consider the following (1) to (13) below:

(1) Namanya sendiri katanya adalah Wati Salsabila yang tidak matching dengan wajahnya merupakan singkatan dari Waduh Mati Salah Sambung Bisa Lahir karena pada waktu kecil seharusnya tidak lahir sebab anak yang ke-10.

'Some one said that her name was Wati Salsabila which is not matched with her face. This name is an abbreviation of Waduh mati salah sambung bisa lahir (Oh my God, even wrong number can be born)'. At that time she should not been born because she was the $10^{\text {th }}$ child'.

(2) Karena ada 10 anak dalam keluarga, tetangganya sering menyebut keluarganya P10, yakni (walaupun tidak tepat betul jumlah P-nya), Putraputrinya Pak Pono Pada Perang Perkara Panganan Peyek.

'Because there were ten children in the family, the neighbors often called her family the ten P, Putra-Putrinya Pak Pono Pada Perang Perkara Panganan Peyek (Mr Pono's children were quarreling because of chip')

(3) Tetangganya namanya seperti nama Spanyol padahal dari Wonogiri, yakni (Iwan) Aldiano singkatan dariAlhamdulilah Dia Nongol karena pada waktu kecil sulit lahir
'Her neighbor's name is like a Spaniard. In fact he is from Wonogiri, that is Iwan Aldino which stands for Alhamdulilah Dia Nongol (Thanks God, finally he comes out) because at that time he was difficult to be born'

(4) Sebenarnya pagi ini saya dipanggil SBY, tapi saya nggak mau, saya lebih berat Stand Up karena nama saya Wati bukan $S B Y$.

'Actually this morning I was called (by) SBY, but I would not come, I would rather chose Stand UP because my name is Wati, not SBY.

(5) Ini HP saya baru masih anget. 'This my hand phone, still hot.

(6) Susu mana bagus di perut.(karena seharusnya di dada)

'How can breasts be good in the stomach because they must be in the chest'

(7) Saya benci ke Mall karena sejak melihat tulisan Jumbo sale - Big sale berarti yang gemuk-gemuk saja yang dijual dan tulisan Sale All Itemberarti yang hitamhitam saja yang dijual.

'I hate going to mall after having seen the ad Jumbo sale - Big sale. It means that they only sell the big (fat), and the ad Sale all item. It means that they only sell the black.

(8) Anak tetangga saya diperkirakan lahir Januari oleh dokter eh ternyata lahir bulan Desember sehingga diberi nama Kukira Januari.

'My neighbor's child was predicted to be born on January, but apparently in December, and then he was named Kukira Januari'.

(9) Ninabobok oh nina bobok Kalau tidak bobok digigit nyamuk (Lagu ini bohong karena sudah tidur tetap digigit nyamuk, dan anaknya sendiri namanya bukan Nina) 
'Sleep my baby, sleep my baby!' 'If you do not sleep, the mosquito will bite you'(This song is not true because the mosquito still bites even the baby has already slept, and the baby's name is not Nina)

(10)Karena nila setitik rusak susu sebelahnya.

'Because of one drop indigo, one side of the breast is rotten'

\section{(11) Anak-anak bisa menyulap radio menjadi nanas. Radio disiram air panas dipegang anak kecil jadi nanas, nanas.}

'Children can conjure up a radio to be a pineapple. The radio is sprayed by hot water, and then the children holding it will scream "hot, hot!"

\section{(12) Tong kosong, mari diisi.} 'An empty barrel, let us fill it!'

\section{(13) Pada saat itu tidak ada tv, satu-satunya hiburan ya hanya itu.}

'At that time, there was no TV, the only amusement was just that activities'

In this episode, the ambiguities are created by various techniques and linguistic manipulations. Abbreviation technique that create a contradiction between part of her elegant Arabic name Salsabila and its real meaning which the shorter form stand for 'Salah sambung bisa lahir' is applied in (1), P 10 that stand for 'Putra-putrinya Pak Pono Pada Perang Perkara Panganan Peyek' (2), and the impressive Italian name Aldiano that poolishly stands for 'Alhamdulillah dia nongol' (3). In (4), (5) and (6) the ambiguity is respectively made possible by the polysemi of Indonesian words interfered by Javanese dipanggil that can mean 'to be invited for a ministry position' and 'is called by the name', anget can be associated with 'new' in relation with 'news' or 'newly copied papers', bagus can mean 'healthy for stomach' and 'its appropriate anatomical position'. In (7) and (8) the ambiguity is caused by the accidental homonyms between Indonesian and English or Japanese like words. Those are between item and item 'a colloquial form for hitam 'black', Kukira 'Japanese name' and kukira 'I think'. This phenomenon is the same as the combination of Nina in Nina Bobok 'title of Indonesian children bed time song' in (9). In (10) the joke is evoked by the ambiguity of susu that can means 'milk' and 'breast' and slight phonetic modification sebelanga 'earthen cooking pot' into sebelahnya 'next side of'. The conventional proverb is Karena nila setitik rusak susu sebalanga 'Because of one drop indigo, one (earthen) cooking pot of milk is rotten'. In (11) the word panas 'hot' is slightly changed into nanas because of children early language acquisition in which they tend to reduplicate the final syllable of words they want to master. The word nanas is accidentlyhomonymous with nanas that means 'pineapple'. Some Indonesian proverbs are so popular that the speaker can identify them without being completely expressed. In (12) the conventional proverb is Tong kosong nyaring bunyinya 'empty barrel has a nice sound' that intended to tease a talkative person with limited knowledge. In this joke the proverb is treated literally to be Tong kosong, mari kita isi 'Empty barrel, let us fill it'. Finally in (13) the ambiguity is caused by several interpretation of word itu 'that'. For euphemistic expression to avoid vulgarism this word can also pragmatically refer to 'sexual activity' that cause her having big family.

The other language plays found in this episode are the film titles which the comedian stars in "Ketika Aku Tidak Ada" (When I did not exist) and "Wanita di Balik Pintu" 'The Woman behind door' implicate that she never acts in any film. A hyperbolic song title "Akan Kupeluk Dia sampai Mati" 'I will hug you until dead' is taken literally to evoke sadistic situation. The Song Lyric Mungkin hanya Tuhan yang Tahu Segalanya 'May be only God knows everything', taken from "Engkaulah Segalanya" 'You are My everything', popularized by Ruth Sahanaya, is considered to hesitate the God's power because of the use of mungkin 'may be, possible'.

The language style used for joking activities will certainly have very different characteristics in various hierarchical 
grammatical and discursive aspects (phonology, lexico-grammar, cohesion, coherence, etc.) compared to other register styles for conducting different activities.

\section{Language functions in Stand Up Comedy}

Language has many communicative functions in human life, and even now no one can count them exactly because the large number of activities that can be carried out by using this verbal human means of communication. In addition, an utterance expressed by the speakers can simultaneously perform two or more functions in every speech event. However, if the language function can simply differentiate into two categories, these are transactional and interactional function, the joking activities found in this Stand Up comedy episode more appropriately belong to the second category, i.e. interactional function. Even though there is also some information want to communicate by the comedian to his/her audience, she seems more concerned to express her criticism on the social conditions in indirect, humorous, and interactive ways. The choice of this mood of interaction are intended to minimize the destructive or aggressive effects of the jokes might bring to the audience. As far as the interactional function is concerned, this language function must also be divided into several subcategories. Apperently, in the earlier version, Halliday in relation to children language acquisition, as cited by Siregar $(2011,5)$, describes his language function theory into seven categories, and the two main categories are a part of them. One of the main categories are given different label, i.e. representative function for ideational function, and transactional function for interpersonal function. Those categories completely are instrumental function for exploiting the circumstance and making certain situation to happen, regulatory function for regulating or controlling situation, representational function for making statement and explain realities, interactional function for keeping on social relationship, personal function for expressing personal feelings, heuristic function for learning science and knowledge, and imaginative function for creating imaginative ideas. Based on this theoretical framework, Wati Salsabila's Stand Up Comedy episode at least conveys three dominant communicative functions, i.e imaginative, personal, interactional and regulatory functions. By imaginative function the comedian create fictional or imaginative stories about herself, her family, and other events occurring in her society. By personal function, she express her feeling and criticism about all of those situation. By interactional function, she use the informal mood of interaction to create intimate relation with the audience in order to elicit their smile and laugh. Finally, by regulatory function she indirectly persuade the audience, especially the authoritative parties to take a part for improvements.

\section{Conclusion}

Joking activities that are commonly considered unimportant or trivial, in fact, play central roles in human life because of their various functions, especially one for criticizing various social conditions happen in the speakers' community. However, to create unaggressive and constructive criticisms, the comedian should build an intimate relation with his/her audience for its effective deliverance. Consequently, $\mathrm{He} /$ she should use certain mood of interaction using informal language style with full of ambiguities that can easily confuse audience's perceptions about many things in order to elicit audience's smile and laugh.

\section{References}

Apte, Mahadev L. 1985. Humor and Laughter. Ithaca. Cornel University Press.

Brown, Gillian \& George Yule. 1983. Discourse Analysisis. Cambridge: Cambridge University

Press. 
Cook, Guy. 2000. Language Play, Language Learning. Oxford: Oxford University Press.

Halliday, M.A.K. 1970. "Language Structure and Language Function". John Lyons (ed.) New Horizons in Linguistics. Harmondsworth. Middx: Penguin Books.

Halliday, M.A.K. 1978. Language As Social Semiotic: The Social interpretation of Language and Meaning. Edward Arnold.

Halliday, M.A.K. \& Hasan, Ruqaiya. 1992. Bahasa, Konteks, dan Teks: Aspek-aspek Bahasa dalam Pandangan Semiotik Sosial. Diterjemahkan oleh Asruddin Barori Tou. Yogyakarta: Gadjah Mada University Press.

Redfern, W. 1984. Puns. Oxford: Blackwell.

Stokhof, W.A.L. 1980. "100 Woisika Riddles". Majalah Ilmu-Ilmu Sastra Indonesia. Jilid IX, No. 1. HIm. 53-101. Jakarta: Fakultas Sastra Universitas Indonesia.

Siregar, Bahren Umar. 2011. Seluk Beluk Fungsi Bahasa. Jakarta. Pusat Kajian Bahasa Universitas Katolik Atma Jaya.

Ulmer, G. 1988. "The Puncept in Gramatology". J Culler (ed.): On Puns: The Foundation of Letters. Oxford: Blackwell.

Wijana, I Dewa Putu. 1995. Wacana Kartun dalam Bahasa Indonesia. Disertasi Doktor. Universitas Gadjah Mada.

Wijana, I Dewa Putu. 2014. Wacana Teka-teki. Yogyakarta: A Com. Press. 